\title{
Effect of the calcinations temperatures of phosphate washing waste on the structural and mechanical properties of geopolymeric mortar
}

\author{
R. Dabbebi ${ }^{\text {a,b,*, J.L. Barroso de Aguiar }}{ }^{\mathrm{b}}$, A. Camões ${ }^{\mathrm{b}}$, B. Samet ${ }^{\mathrm{a}}$, S. Baklouti ${ }^{\mathrm{a}}$ \\ a University of Sfax, Laboratory of Industrial Chemistry, Sfax 3038, Tunisia \\ ${ }^{\mathrm{b}}$ University of Minho, C-TAC Research Centre, Guimarães 4800-058, Portugal
}

\section{H I G H L I G H T S}

- Phosphate washing waste is one of phosphate sub product.

- The calcined phosphate washing waste was used as geopolymer precursors.

- The performance and the formed phases after alkali activation depend with calcination temperature.

\section{A R T I C L E I N F O}

\section{Article history:}

Received 25 March 2018

Received in revised form 20 June 2018

Accepted 9 July 2018

\section{Keywords:}

Phosphate washing waste

Geopolymeric mortar

Sodium hydroxide

Sodium silicate

\begin{abstract}
A B S T R A C T
The phosphate industry is facing serious environmental problems. This issue is caused by the waste after the extraction of the phosphate ore. The waste termed as phosphate washing waste (PWW) was filtered and dried at $105{ }^{\circ} \mathrm{C}$ for $24 \mathrm{~h}$ to remove the water. The dried PWW was milled, sieved in a $100 \mu \mathrm{m}$ sieve and characterized by X-ray fluorescence (XRF). The resulting waste was calcined at 600,700 and $800{ }^{\circ} \mathrm{C}$, the calcined and uncalcined waste were investigated by X-ray powder diffraction (DRX), Fourier transform infrared (FTIR), simultaneous differential thermal and thermogravimetric analyses (DSC-TG) and scanning electron microscope (SEM). The PWW was activated with sodium hydroxide $(\mathrm{NaOH})$ and sodium silicate to produce geopolymeric materials. It was found that the calcination temperature and the extra water added to the mixture to assure the good workability play an important role on the development of the system's workability and compressive strength.
\end{abstract}

(c) 2018 Elsevier Ltd. All rights reserved.

\section{Introduction}

The solid waste generation have considerably accelerated because of the fact that the global population increase, rapid urbanization and consumption [1]. The global quantities of solid waste generation such as factories mills and mines waste were about 11 billion tons per years. This waste is mainly created by the use of natural resources, every year about 120-130 billion tons of natural sources are consumed [2]. This large amount of waste is one of the major problems which leads to severe environmental pollution and significant land occupation. There are numerous type of industrial waste such as mining waste, processing waste and metallurgical waste [3-5]. The recycling and reuse of these waste is important ways to conserve some of the natural resources for the new generation, save energy, reduction of costs, practical application, financial returns and encourage innovation [4]. These

\footnotetext{
* Corresponding author at: University of Sfax, Laboratory of Industrial Chemistry, Sfax 3038, Tunisia.

E-mail address: dabbebirawia@gmail.com (R. Dabbebi).
}

industrial wastes were differently reused by numerous researchers to reduce its load by exploitation as alternative in different fields like the Table 1 shows.

Phosphate ore is one of important minerals in the world. According to industry analyst, its production was about 147 million tons in 2017, which can increase to reach 168 million tons in 2021 [6]. This rock mine is one of essential product extracted by Gafsa Phosphate Company (CPG). It extracts an average of about 8 million of rocks in recent years [7]. Tunisian phosphate ore is composed by fluorapatite, silica, carbonate (calcite), gypsum, organic and aluminosilicates materials [7-9]. This ore is used in the production of phosphoric acid and as fertilizer to be used in agriculture and other fields [10]. To increase the percentage of $\mathrm{P}_{2} \mathrm{O}_{5}$ and produce nearly $80 \%$ of phosphate ore for commercial use, the ore was enriched by the extraction of the gangue such as aluminosilicates, silica and carbonate. The CPG use the washing and flotation as techniques to eliminate these components. These operations create a large volume of waste which generates real damage to the environment. 
Table 1

Data collection related to the use of waste as alternative in different fields.

\begin{tabular}{|c|c|c|}
\hline Wastes & Alternative & References \\
\hline \multirow[t]{4}{*}{ Fly ash } & Alkali activated materials & [11-13] \\
\hline & Geopolymer materials & [14-16] \\
\hline & Removal of heavy metals & {$[5]$} \\
\hline & Synthesis of zeolites & [17] \\
\hline \multirow[t]{5}{*}{ Ceramic waste } & Thermal protective coating TPC & [18] \\
\hline & Geopolymer materials & [19] \\
\hline & Aggregate & {$[20]$} \\
\hline & Building materials & {$[3,21]$} \\
\hline & Synthesis of zeolites & {$[22]$} \\
\hline \multirow[t]{4}{*}{ Blast furnace slag } & Alkali activated materials & [23] \\
\hline & Geopolymer materials & [15] \\
\hline & Removal of heavy metal & [5] \\
\hline & Glass -ceramic & {$[24]$} \\
\hline \multirow[t]{5}{*}{ Waste glass } & Aggregates & [25-27] \\
\hline & Geopolymer materials & [25] \\
\hline & Building materials & {$[28]$} \\
\hline & Alkali activated materials & [29] \\
\hline & Ceramic & {$[30]$} \\
\hline \multirow[t]{3}{*}{ Red mud } & Geopolymer materials & {$[25]$} \\
\hline & Synthesis of zeolite & {$[31]$} \\
\hline & ceramic & [32] \\
\hline \multirow[t]{3}{*}{ Steel slag } & Geopolymer materials & [33] \\
\hline & Cement and concrete & {$[34,4]$} \\
\hline & ceramic & [35] \\
\hline \multirow[t]{5}{*}{ Phosphate sub-product } & Recovery of waste water & [36] \\
\hline & Building materials & {$[37-40]$} \\
\hline & Membrane & {$[41,42]$} \\
\hline & Ceramic & [43] \\
\hline & lightweight & [44] \\
\hline
\end{tabular}

This waste has different names used in the literature [38] which are phosphate sub-group $[41,42]$, phosphate slimes $[36,45,46]$ and phosphate tailing $[38,43,47]$. This waste can be divided in two categories. The first is the waste with particle size more than $2 \mathrm{~mm}$ and the second is the waste with particle size less than $70 \mu \mathrm{m}$ [8]. The last was stored in a pond with around dozen hectares [44] as shown in the Fig. 1 and named phosphate slimes or phosphate washing waste (PWW).

Based on previous research of the phosphate ore, these two types of waste contain probably quartz, carbonates, aluminosilicates and fluorapatite with consideration of the mineralogical composition of phosphate rocks [9,48-50]. These wastes were used and valorised in different fields [51,52]: ceramic industry [26,53], brick manufacture and aggregate production for road and concrete $[44,54]$. In accordance to the literature, no studies have dealt with the reuse of Tunisian PWW. The composition of the PWW can be suitable for the synthesis of many products like ceramics and alkali activated materials (geopolymeric materials).

Geopolymer is a subclass of alkali activated materials. This term was applied for the first time in 1970 by Davidovits [55]. This material is inorganic polymer with lower $\mathrm{CO}_{2}$ footprint. It is produced from a large number of natural minerals [56,57] or industrial waste $[12-15,18,25,33,56,58]$ activated by an alkaline solution at ambient or slightly high temperature. It presents sometimes problems of cost and durability [59].

The geopolymeric mortars are composed of basic components such as aluminosilicate precursor, sand and alkali activator solution which can be basic or acid [60-62], and by supplementary materials like extra water, plasticizer and fiber.

This study focuses on the synthesis and the characterization of geopolymeric mortars based on the Tunisian PWW calcined at different temperatures.

\section{Experimental work}

\subsection{Materials}

The phosphate washing waste used in this study was taken from Metlawi's storage ponds (LaveriesIV), a region in the south of Tunisia. The waste was in the form of slurry containing a flocculent. The slurry is filtered and dried at $105^{\circ} \mathrm{C}$ for $24 \mathrm{~h}$ to remove the water. The dried PWW was crushed and sieved to the grain size less than $100 \mu \mathrm{m}$, then the powder was calcined at 3 different temperatures $600{ }^{\circ} \mathrm{C}$ $700{ }^{\circ} \mathrm{C}$ and $800^{\circ} \mathrm{C}$ for $2 \mathrm{~h}$ with heating rate $10 \% \mathrm{~min}$ in a muffle furnace $\mathrm{LAB}$ TechDaihan LAB TECH CO. LTD.

\subsection{Experimental techniques}

The obtained powder was characterized with X-ray fluorescence(Philips X UNIQUE II), X ray diffraction (XRD) model Bruker D8 Discover with $\mathrm{Cu} K \alpha$ radiation $\lambda=1.54060 \AA$ at $40 \mathrm{kV}$ and $40 \mathrm{~mA}$, the sample was scanned from $5^{\circ}$ to $60^{\circ}$ at a speed of $0.02^{\circ} \mathrm{s}^{-1}$, and by the Fourier transform infrared (FTIR) model Perkin Elmer spectrum BX spectrophotometer apparatus in transmittance mode in the wave number range between 4000 and $400 \mathrm{~cm}^{-1}$. The grain size was measured by laser diffraction (FRITSCH Analysette 22 MicroTec plus). The microstructure observations of the samples were performed using a scanning electron microscope SEM 200 operating at $15 \mathrm{kV}$. The samples were sputter coated with $40 \mathrm{~nm}$ film of Au-Pd (80-20 wt\%) prior of the analysis. DSC-TGA of the samples were done by TA Instruments SDT 2960 Simultaneous DSC-TGA under argon atmosphere with heating rate 10 ${ }^{\circ} \mathrm{C} / \mathrm{min}$ from room temperature to $1000{ }^{\circ} \mathrm{C}$.

\subsection{Geopolymeric mortars preparation}

The composition of the mixtures is presented in the Table 2 . The powder calcined at 3 different temperatures $600{ }^{\circ} \mathrm{C}, 700^{\circ} \mathrm{C}$ and $800^{\circ} \mathrm{C}$ were activated using alkaline solutions based on: sodium hydroxide $\mathrm{NaOH}$ solution $10 \mathrm{M}(\mathrm{SH})$, and sodium silicate solution $\mathrm{Na}_{2} \mathrm{SiO}_{3}$ (SS) with chemical composition $\mathrm{Na}_{2} \mathrm{O}\left(\mathrm{SiO}_{2}\right)_{\mathrm{x}} \cdot \mathrm{y}$ $\left(\mathrm{H}_{2} \mathrm{O}\right)$ with $3.19<\mathrm{x}<3.53$ and $50 \%<\mathrm{y}<60 \%$ from the Portuguese Industry MERKANDA. The $\left(\mathrm{Na}_{2} \mathrm{SiO}_{3} / \mathrm{NaOH}\right)$ ratio is of the order of 1 .

First the solution of $\mathrm{NaOH} 10 \mathrm{M}$ was prepared with water and pellets of $\mathrm{NaOH}$ and after $24 \mathrm{~h}$ it was mixed with the sodium silicate solution. The mortar compositions were determined for a unitary volume of $1 \mathrm{~m}^{3}$ [63]. This method takes into account the densities of the materials present in the Table 3. First the liquid/solid ratio was fixed after preliminary essays, next the needed quantities of the extra water and the sand were determined to obtain the adequate workability for the geopolymeric mortars. The calcined PWW powder and the sand were mixed first for $30 \mathrm{~s}$, then the alkali solutions and extra water were added and all the mixture was mixed for $90 \mathrm{~s}$ with low speed and other $90 \mathrm{~s}$ with high speed. Right after mixing the mortar, the flow table test of fresh geopolymeric mortar was determined in conformity with the European Standard EN1015-3 [64]. The diameter obtained with each measurement was only considered when equal to $150 \pm 1 \mathrm{~mm}$. The mortar was placed in the mold with $50 \times 50 \times 50 \mathrm{~mm}^{3}$. Then, the molds were vibrated for $30 \mathrm{~s}$ with a vibration table to eliminate the air bubbles. The samples were covered with a

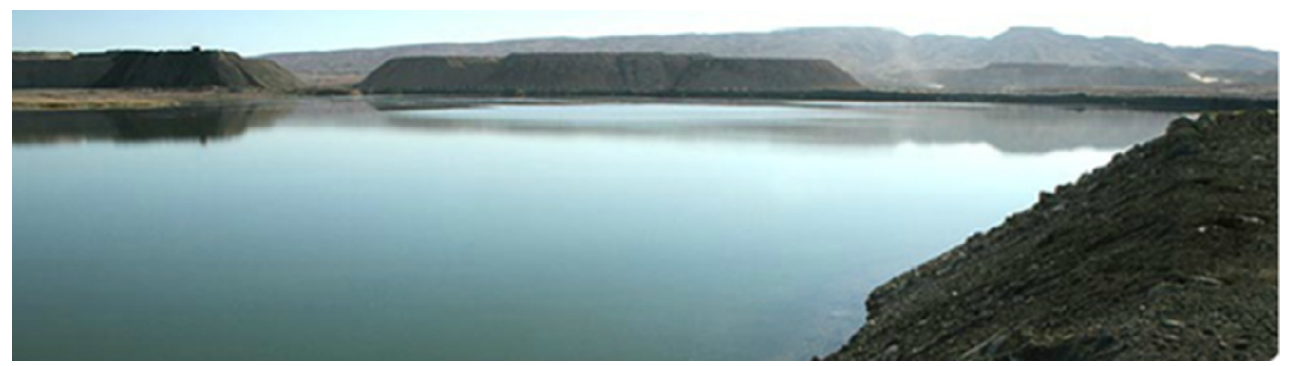

Fig. 1. Tunisian phosphate washing waste pond 
Table 2

Designation and geopolymeric mortar formulation $\left(\mathrm{kg} / \mathrm{m}^{3}\right)$.

\begin{tabular}{|c|c|c|c|c|c|c|}
\hline & $\mathrm{L} / \mathrm{B}$ & Binder & SS & SH $10 \mathrm{M}$ & Extra water & Sand \\
\hline $\mathrm{G}_{0.9}^{600}$ & 0.9 & 500 & 170 & 170 & 110 & 1162 \\
\hline $\mathrm{G}_{0.85}^{700}$ & 0.85 & 500 & 170 & 170 & 85 & 1223.8 \\
\hline $\mathrm{G}_{0.8}^{800}$ & 0.8 & 500 & 170 & 170 & 60 & 1298.1 \\
\hline
\end{tabular}

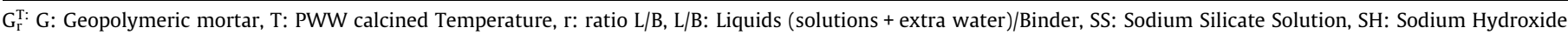
Solution.

Table 3

Densities of the calcined PWW, sand and the alkali solution.

\begin{tabular}{|c|c|c|c|c|c|c|}
\hline Elements & $\mathrm{B}_{600}$ & $\mathrm{~B}_{700}$ & $\mathrm{~B}_{800}$ & SS & SH 10M & Sand \\
\hline Densities & 2670 & 2660 & 2720 & 1460 & 1307 & 2547 \\
\hline
\end{tabular}

$\mathrm{B}_{\mathrm{T}}$ : B: Binder, T: Temperature.

vinyl sheet to block the moisture loss for $24 \mathrm{~h}$. The next day the mortars were demolded and covered again by the vinyl sheet and left in the laboratory at ambient temperature to be tested and characterized at 7 and 28 days.

The compressive strength was the average of three tests specimens. The SEM, XRD and DSC analysis of the samples were performed at 7 and 28 days.

\section{Results and discussions}

\subsection{Raw materials characterization}

\subsubsection{Particle size distribution}

The Fig. 2 shows the particle size analysis of PWW in the state of slurry. The distribution of the particle size is bimodal. The most dominant is between 0.9 and $60 \mu \mathrm{m}$ and the majority of particles in this zone have a diameter $\sim 7.5 \mu \mathrm{m}$. The less dominant population is between 60 and $250 \mu \mathrm{m}$, with great part of particles have an approximate diameter of $100 \mu \mathrm{m}$. The presence of these two populations of the particle size can be explained by the use of the flocculent by the company during ore phosphate beneficiation to recover the maximum of water.

\subsubsection{Chemical composition of PWW}

The data in the Table 4 shows the chemical composition of the PWW, and display that the silica, the calcium, the aluminium and the phosphorus are present in major quantities while the other elements are present in trace amount. The results of PWW analysis confirm the chemical composition of the phosphate ore [7]. The result displays the $\mathrm{Ca} / \mathrm{P}$ ratio which is $\sim 2.65>1.67$. this ratio increased, first with the substitution of $\mathrm{PO}_{4}^{3-}$ by $\mathrm{CO}_{3}^{2-}$ in the structure of fluorapatite [65] or it indicates the presence of carbonates e.g. Calcite.

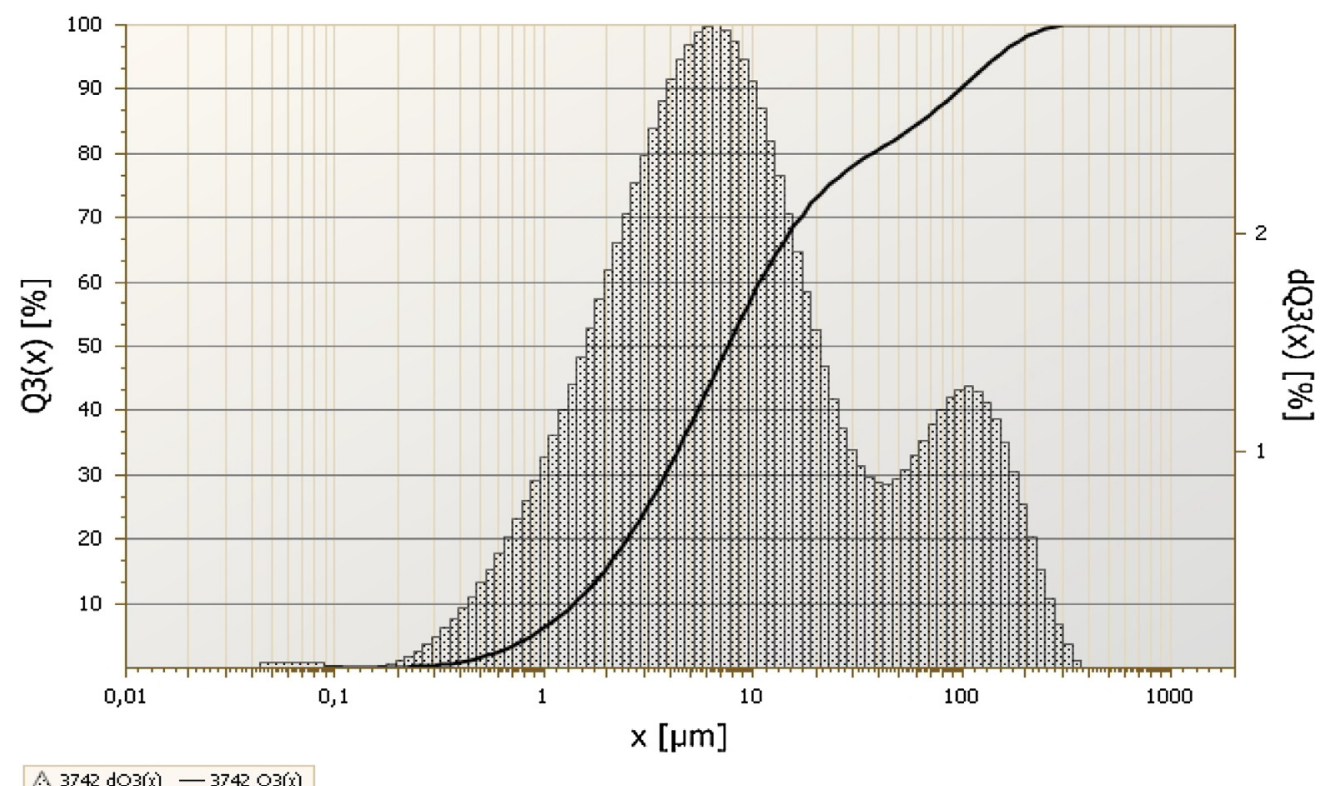

Fig. 2. Particle size analysis of phosphate washing waste.

Table 4

Chemical composition of PWW.

\begin{tabular}{|c|c|c|c|c|c|c|c|c|c|c|c|}
\hline Oxides & $\mathrm{SiO}_{2}$ & $\mathrm{CaO}$ & $\mathrm{P}_{2} \mathrm{O}_{5}$ & $\mathrm{Al}_{2} \mathrm{O}_{3}$ & $\mathrm{Na}_{2} \mathrm{O}$ & $\mathrm{K}_{2} \mathrm{O}$ & $\mathrm{MgO}$ & $\mathrm{SO}_{3}$ & $\mathrm{Fe}_{2} \mathrm{O}_{3}$ & $\mathrm{~F}_{2} \mathrm{O}$ & LOI \\
\hline$\%$ & 42 & 26.5 & 10 & 9.77 & 1.12 & 0.673 & 3.09 & 3.39 & 2.31 & 0.96 & 17 \\
\hline
\end{tabular}

LOI: loss on ignition. 


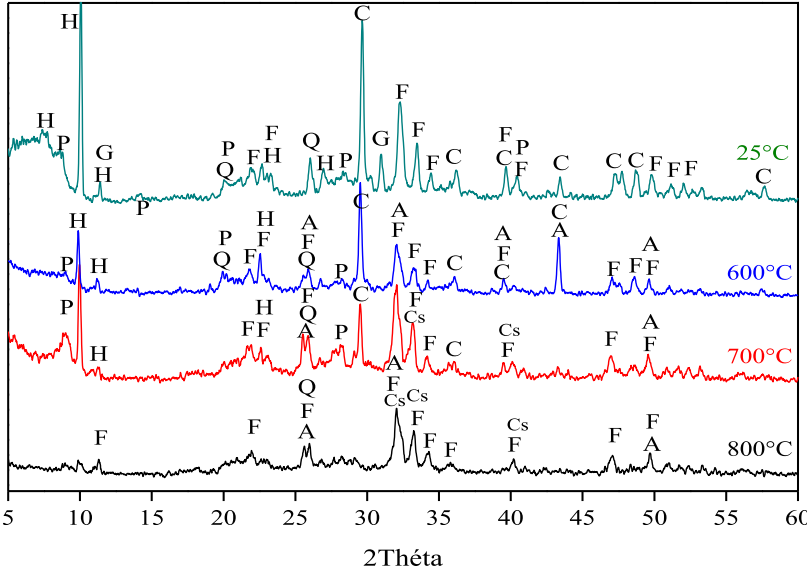

Fig. 3. $\mathrm{X}$ ray diffractograms of the $\mathrm{PWW}$ uncalcined and calcined at $600{ }^{\circ} \mathrm{C}, 700^{\circ} \mathrm{C}$ and $800^{\circ} \mathrm{C}$. C: Calcite, H: Heulandites, G: Gypsum, Q: Quartz, F: Fluorapatite, P: Palygorskite A: Anhydrite, Cs: $\mathrm{C}_{2} \mathrm{~S}$.

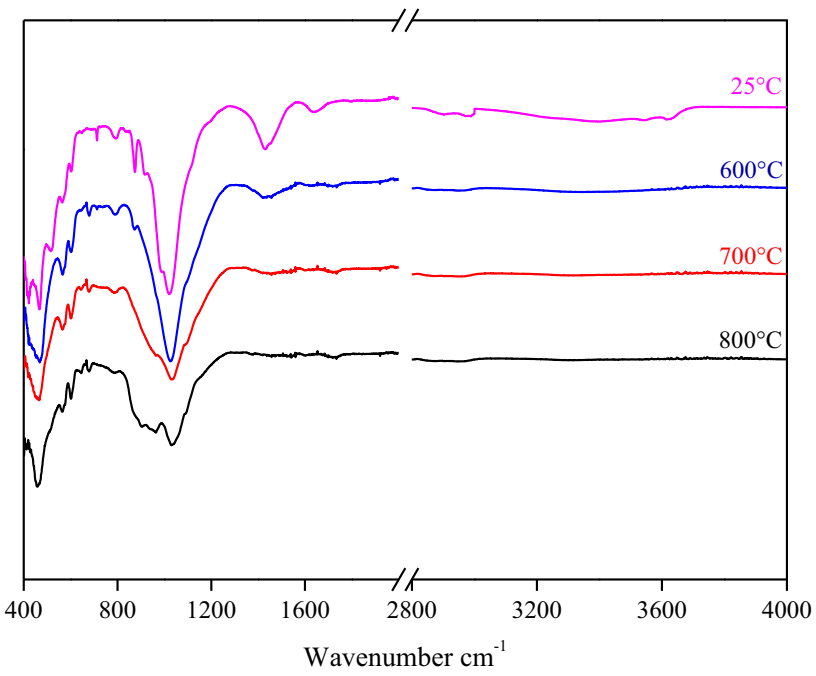

Fig. 4. FTIR of phosphate washing waste at different temperatures $400-4000 \mathrm{~cm}^{-1}$.

\subsubsection{XRD characterization}

The Fig. 3 shows the $\mathrm{X}$ ray diffractgrams of the PWW at $25^{\circ} \mathrm{C}$, 600,700 and $800{ }^{\circ} \mathrm{C}$. The pattern of PWW at $25^{\circ} \mathrm{C}$ shows the presence of carbonates essentially as a calcite at $3 \AA \AA$. It displayed peaks at $8.76 \AA$ indicating the presence of natural zeolite heulandites as main aluminosilicate mineral.

The PWW contain also a fibrous clay palygorskite showed by peak at $10.09 \AA$, a small amount of quartz with a peak at $3.41 \AA$ and gypsum with a peak at $2.8 \AA$.

\subsubsection{FTIR characterization}

The infrared spectra of the PWW at $25^{\circ} \mathrm{C}$ in Fig. 4 shows that the uncalcined sample presents the $\mathrm{H}-\mathrm{O}-\mathrm{H}$ bending and hydroxyl group $\left(\mathrm{OH}^{-}\right)$respectively by the 2 bands at 1636 and $3611 \mathrm{~cm}^{-1}$. The organic material was shown by the presence of the band at $2981 \mathrm{~cm}^{-1}$. Other elements are also identified and confirmed the XRD diffractograms, such as the palygorskite by the bands at 418 , $516,917 \mathrm{~cm}^{-1}$ of $\mathrm{Si}-\mathrm{O}, \mathrm{Si}-\mathrm{O}$ and $\mathrm{Al}-\mathrm{OH}-\mathrm{Al}$ respectively [66]. The fluorapatite was identified by the bands at 466, 567 and 604 $\mathrm{cm}^{-1}$ of $\mathrm{PO}_{4}^{3-}$ and [67]. The calcite shows three bands of $\mathrm{CO}_{3}^{2-}$ at $712,875,1431 \mathrm{~cm}^{-1}[68,69]$. The FTIR curves show the presence of a weak band at $653 \mathrm{~cm}^{-1}$ corresponding to $\mathrm{SO}_{4}^{3-}$ of gypsum [70].

\subsubsection{SEM observation}

The SEM analysis in Fig. 5A shows that the particles are heterogeneous with irregular shape. The PWW at ambient temperature has a strong tendency to agglomerate with the presence of solid deposits, small crystals and needles shown in Fig. 5B.

\subsubsection{Dsc-tg}

The Fig. 6 shows the thermal behaviour of PWW, the first mass loss is $2.350 \%$ was at around $100{ }^{\circ} \mathrm{C}$ coupling by an endothermic peak in the DSC curve corresponds to the remove of adsorbed water (moisture). The second mass loss was between 200 and $550{ }^{\circ} \mathrm{C}$ with a value $\sim 4.69$ mass\% correspond first to the liberation of the zeolitic water localized in the cavities and channels of the natural zeolite [71] at $203{ }^{\circ} \mathrm{C}$ leading a structure destruction and a second loss due to the combustion of the organic matter characterized by an exothermic peak at $552{ }^{\circ} \mathrm{C}$. The third mass loss is reflecting the decomposition of carbonates calcite $\mathrm{CaCO}_{3}$ during heating, it reaches a value $\sim 9.96 \%$ with the release of $\mathrm{CO}_{2}$ and it is characterized by an endothermic peak at $730^{\circ} \mathrm{C}$.
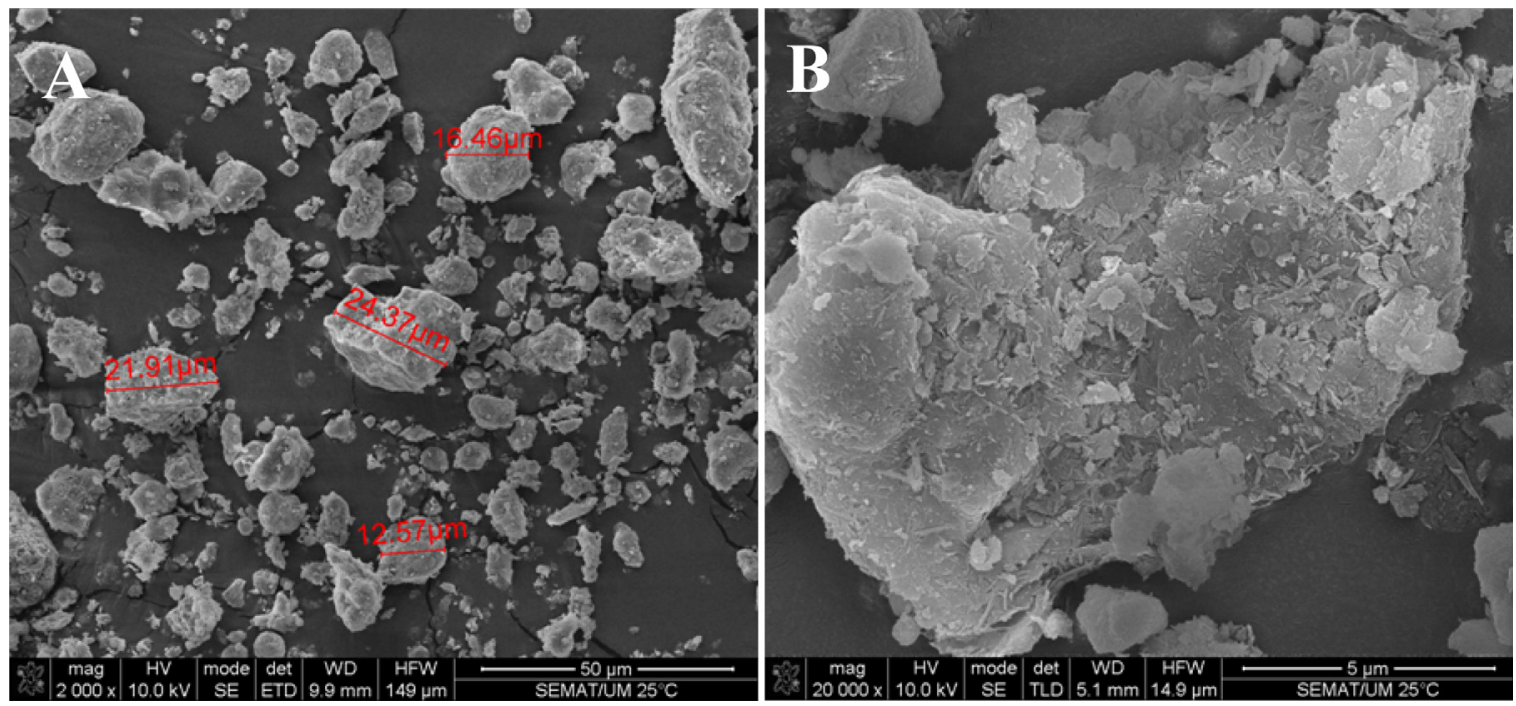

Fig. 5. SEM of phosphate washing waste. 


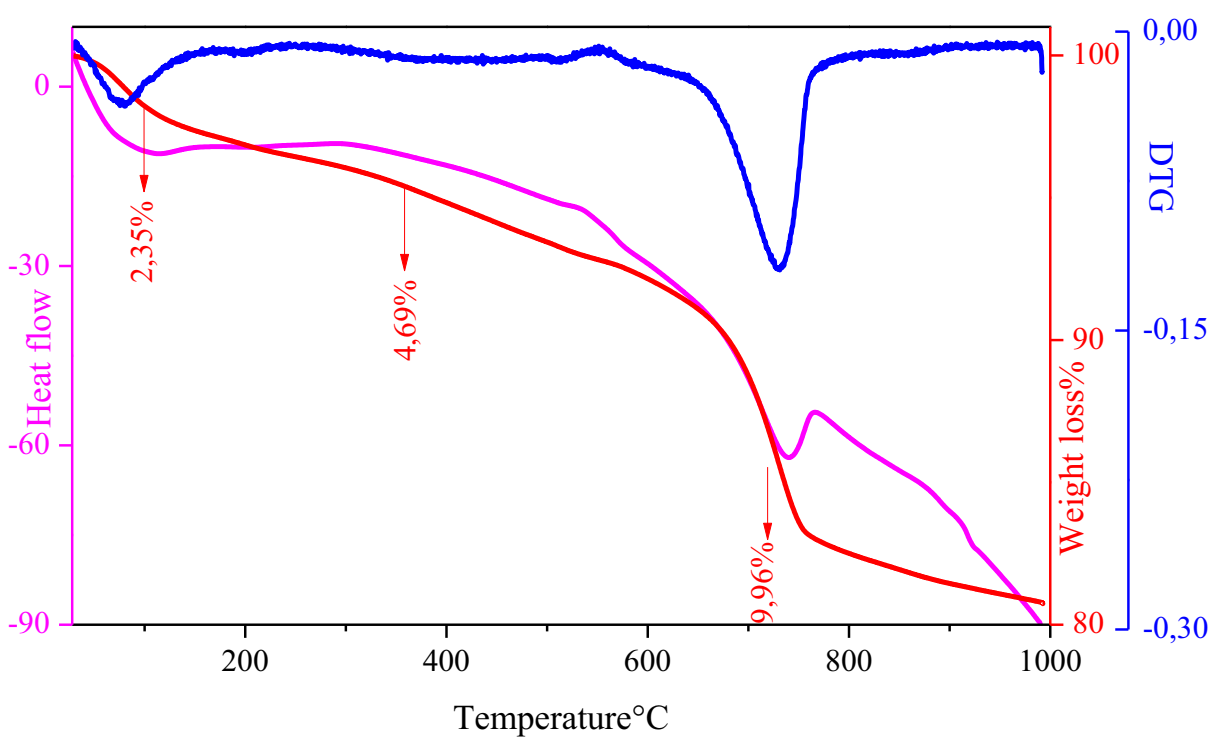

Fig. 6. DSC-TGA of phosphate washing waste.

The calcination interval of PWW was based on the results of its thermal behaviour. It was calcined at 3 different temperatures $600{ }^{\circ} \mathrm{C}$ the start of decarbonation, $700{ }^{\circ} \mathrm{C}$ the decarbonation and the end of zeolite structure destruction and $800{ }^{\circ} \mathrm{C}$ the end of the decarbonation process, to study the effect of temperature on the phases present in the PWW and on the geopolymeric mortars.

\subsection{Calcined PWW characterization}

\subsubsection{XRD characterization of $P W W$ at 3 different temperatures}

The Fig. 3 shows the XRD of the PWW calcined at $600^{\circ} \mathrm{C}, 700{ }^{\circ} \mathrm{C}$ and $800^{\circ} \mathrm{C}$. The patterns show crystalline and amorphous phases which important for the powder calcined at $700{ }^{\circ} \mathrm{C}$ compared to the powder calcined at $600^{\circ} \mathrm{C}$ and $800{ }^{\circ} \mathrm{C}$. It displays that the fluorapatite mineral still appears after calcinations at the 3 different temperatures. The curves show also that the calcite, palygorskite, heulandites phases were progressively decreased until disappeared at $800^{\circ} \mathrm{C}$. This decrease of the calcite phase is related to the decarbonation like the DSC-TG shows. For the heulandites, the decrease was related to the effect of the temperature on the decomposition of the heulandites structure [72]. In addition, reflections of new phases appear like the anhydrite from $600{ }^{\circ} \mathrm{C}$ and the $\mathrm{C}_{2} \mathrm{~S}$ from $700{ }^{\circ} \mathrm{C}$.

3.2.1.1. FTIR characterization of PWW at 3 different temperatures. The FTIR spectra of the calcined samples presented in the Fig. 4 show that the sharp band at $3611 \mathrm{~cm}^{-1}$ of $\mathrm{OH}^{-}$stretch and the band at $1636 \mathrm{~cm}^{-1}$ which correspond to $\mathrm{H}-\mathrm{O}-\mathrm{H}$ bending were vanished totally from $600{ }^{\circ} \mathrm{C}$. The band which corresponds to the organic matter at $2891 \mathrm{~cm}^{-1}$ disappears by calcination. The characteristic band of calcite becomes extinct at $800^{\circ} \mathrm{C}$. Furthermore, the bands of $\mathrm{PO}_{4}^{3-}$ of the fluorapatite persist at $600{ }^{\circ} \mathrm{C}, 700{ }^{\circ} \mathrm{C}$ and $800{ }^{\circ} \mathrm{C}$. The weak band at $25^{\circ} \mathrm{C}$ of the $\mathrm{SO}_{4}^{3-}$ becomes more intense after calcinations because the concentration increases of the $\mathrm{SO}_{4}^{3-}$ in the calcined powder. The most intense band at $1021 \mathrm{~cm}^{-1}$, which corresponding to stretching band of $\mathrm{Si}-\mathrm{O}$, remains in all the spectra with different intensities.

3.2.1.2. SEM observation. The microstructure of the uncalcined PWW and calcined at $600{ }^{\circ} \mathrm{C}, 700^{\circ} \mathrm{C}$ and $800^{\circ} \mathrm{C}$ in the Fig. 7 present a change of the composition due to the process of heating and its effect on the matrix of the phosphate washing waste. The morphol- ogy did not change from a temperature to another with edge size ranging from 2 to $10 \mu \mathrm{m}$.

\subsection{Geopolymeric mortars characterization}

\subsubsection{Workability}

The liquid/binder ratio required for workability range between 14 and $16 \mathrm{~cm}^{-1}$, decrease with the increase of the calcination temperature of the PWW. Fig. 8a presents the workability of the mixture $G_{0.8}^{800}$ that has a problem during mixing. The mixture was dried and hardened just $2-5$ min after mixing as shown in Fig. 8b. This can be explained probably that upon mixing of the mortar ingredients, the $\mathrm{CaO}$ dissolved in the alkaline solution. The dissolved $\mathrm{Ca}^{2+}$ came in contact with $\mathrm{OH}^{-}$present in the water and formed calcium hydroxide $\mathrm{Ca}(\mathrm{OH})_{2}$ which cause the quick hardening [73].

The mixtures $G_{0.9}^{600}$ and $G_{0.85}^{700}$, presents a good workability 15 and $16 \mathrm{~cm}$ respectively.

The obtained PWW geopolymeric mortars $\mathrm{G}_{0.9}^{600}$ and $\mathrm{G}_{0.85}^{700}$ were characterized by SEM, DSC-TG, and XRD and mechanically characterized by compressive strength.

\subsection{2. $X R D$ characterization}

The Fig. 9 reports the XRD of $G_{0.9}^{600}$ and $G_{0.85}^{700}$ at 7 and 28 days which represent both amorphous and crystalline phases. Comparing the XRD spectra of the calcined PWW at $600{ }^{\circ} \mathrm{C}$ and $700{ }^{\circ} \mathrm{C}$ with those of the hardened samples, it can be seen that the crystalline phases originally existing Heulandites, palygorskite and anhydrite disappeared. Traces of calcite can be detectable in the geopolymeric mortars from the calcined materials and some from the carbonation reaction of the samples. The patterns show also that the fluorapatite have not been apparently altered by the alkali solution. The XRD patterns of $\mathrm{G}_{0.9}^{600}$ show also the formation of crystalline phase which is a zeolite at 7 days with small amount showed by a weak reflection and it is become more intense at 28 days. In these patterns, the peaks of quartz appear more intensely than that appears in the calcined materials. This is due to some particle of sand used as aggregate, which could not be totally eliminated during the preparation of XRD samples. Furthermore, a crystalline sodium compounds did not appear in the XRD patterns, it could be assumed that the sodium was included in the amorphous geopolymers phase. 


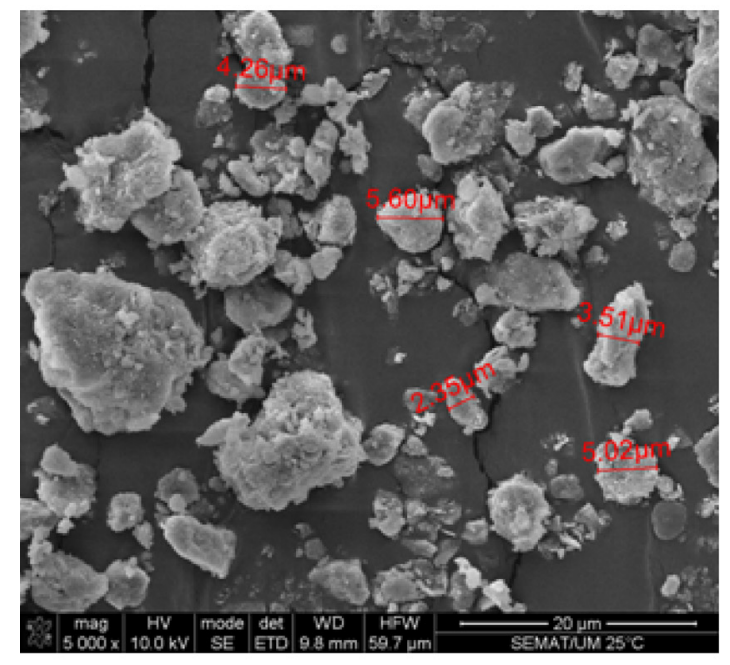

A) $25^{\circ} \mathrm{C}$

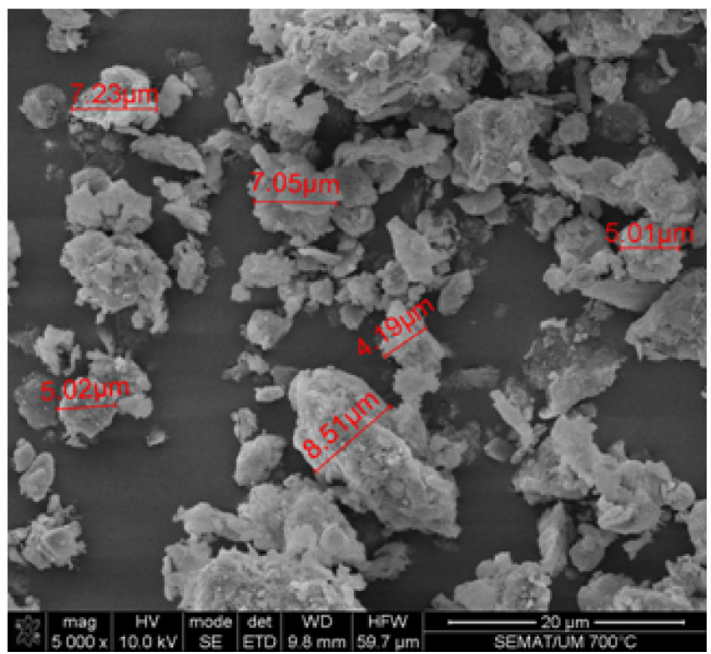

C) $700^{\circ} \mathrm{C}$

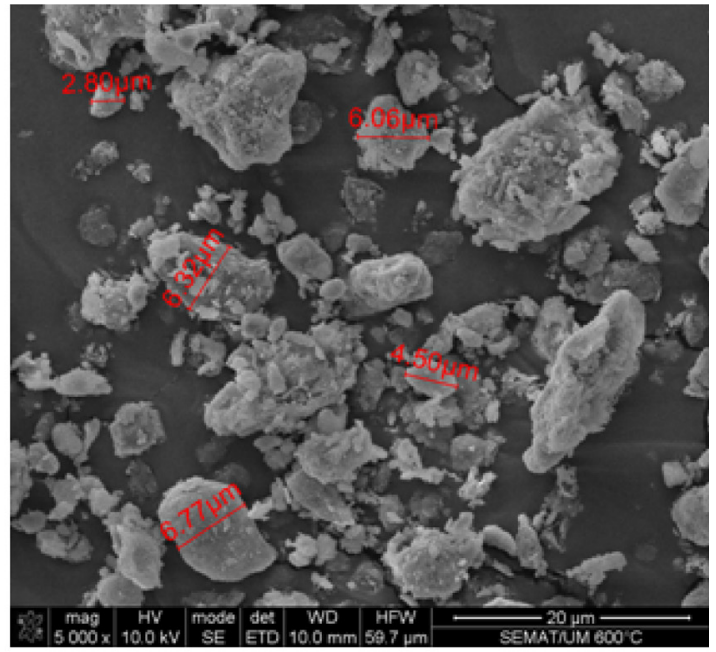

B) $600^{\circ} \mathrm{C}$

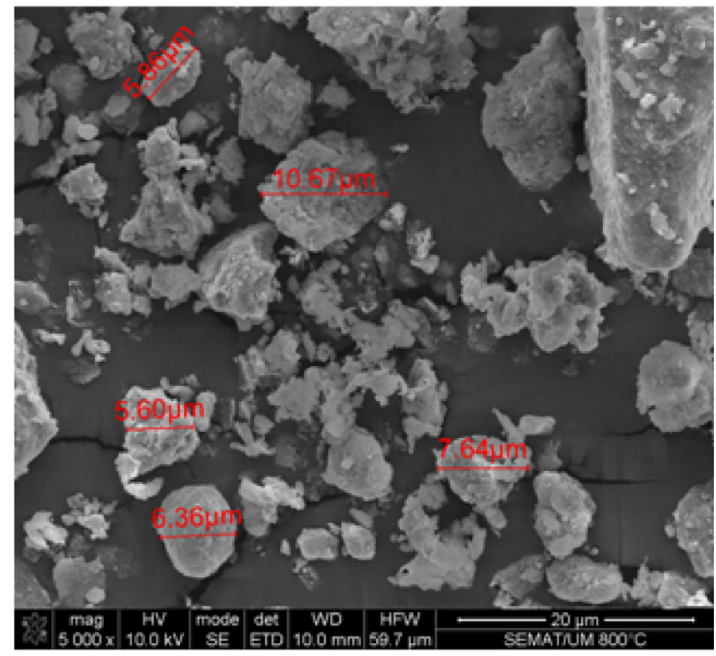

D) $800^{\circ} \mathrm{C}$

Fig. 7. Particle size of PWW at differnt temperatures.
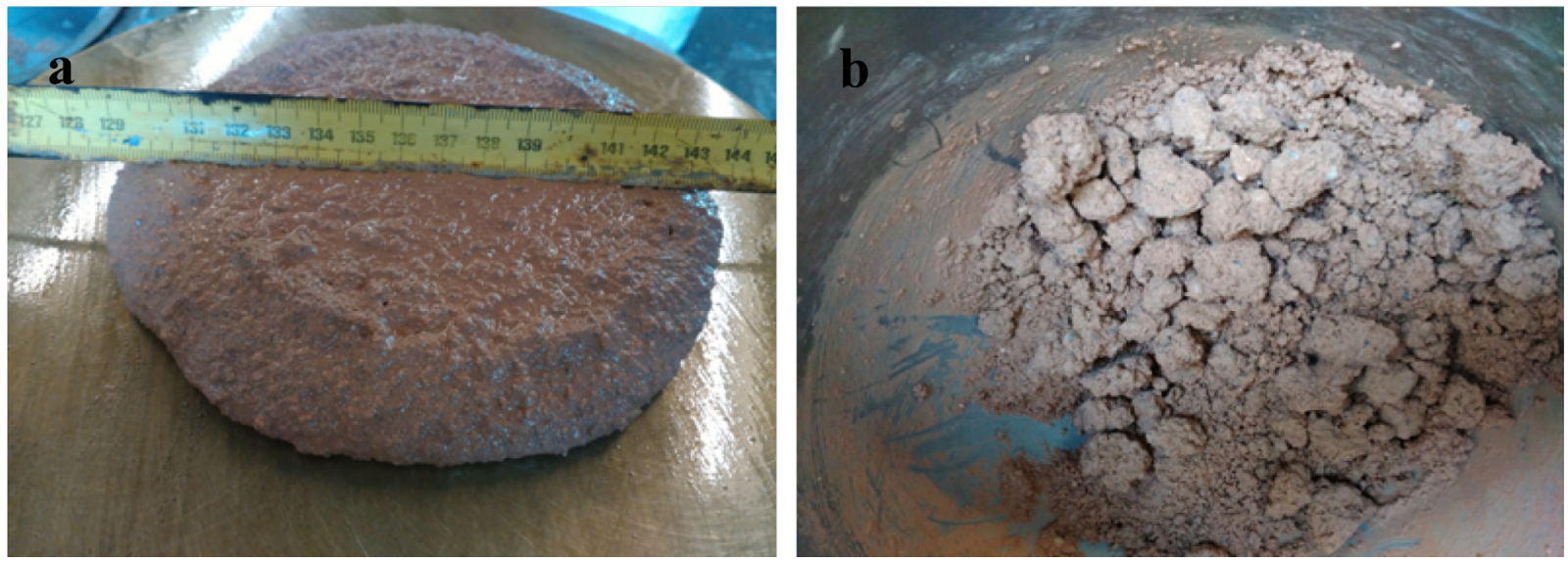

Fig. 8. Performance of the $\mathrm{G}_{0.8}^{800}$ mixture. 

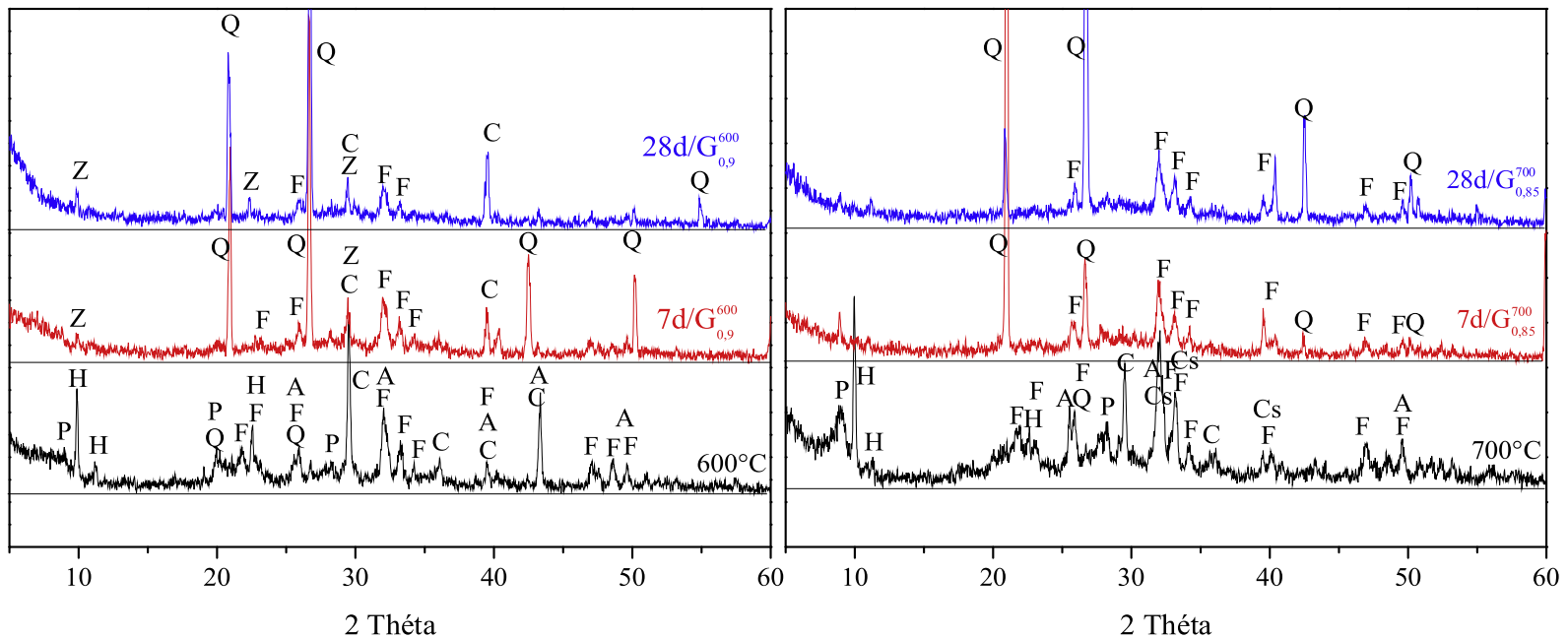

Fig. 9. XRD of geopolymeric mortars at 7 and 28 days. Q:Quartz, H: Heulandite, C: Calcite, Z : zeolite, F: Fluorapatite, Cs : $C_{2} S$.

\subsubsection{DCS-TGA test}

The geopolymeric mortars are heated under argon atmosphere at $10^{\circ} \mathrm{C} / \mathrm{min}$ up to $1000^{\circ} \mathrm{C}$, the differential scanning calorimetric and thermogravimetric (DSC-TG) were depicted in Fig. 10.

It can be seen that all the samples show a first endothermic peak at $\sim 70-90{ }^{\circ} \mathrm{C}$ in the DSC curves reflecting the loss of uncombined and weakly absorbed water within the matrix which results in a substantial mass loss observed at the same temperature range in the TG analysis. For the $G_{0.9}^{600}$ and $G_{0.85}^{700}$, the curves show that the mass loss at 7 days was about $7 \%$ and at 28 days it become $15 \%$, and this can be interpreted by the development of the geopolymerisation reaction which leads to the liberation of water as a product [74].
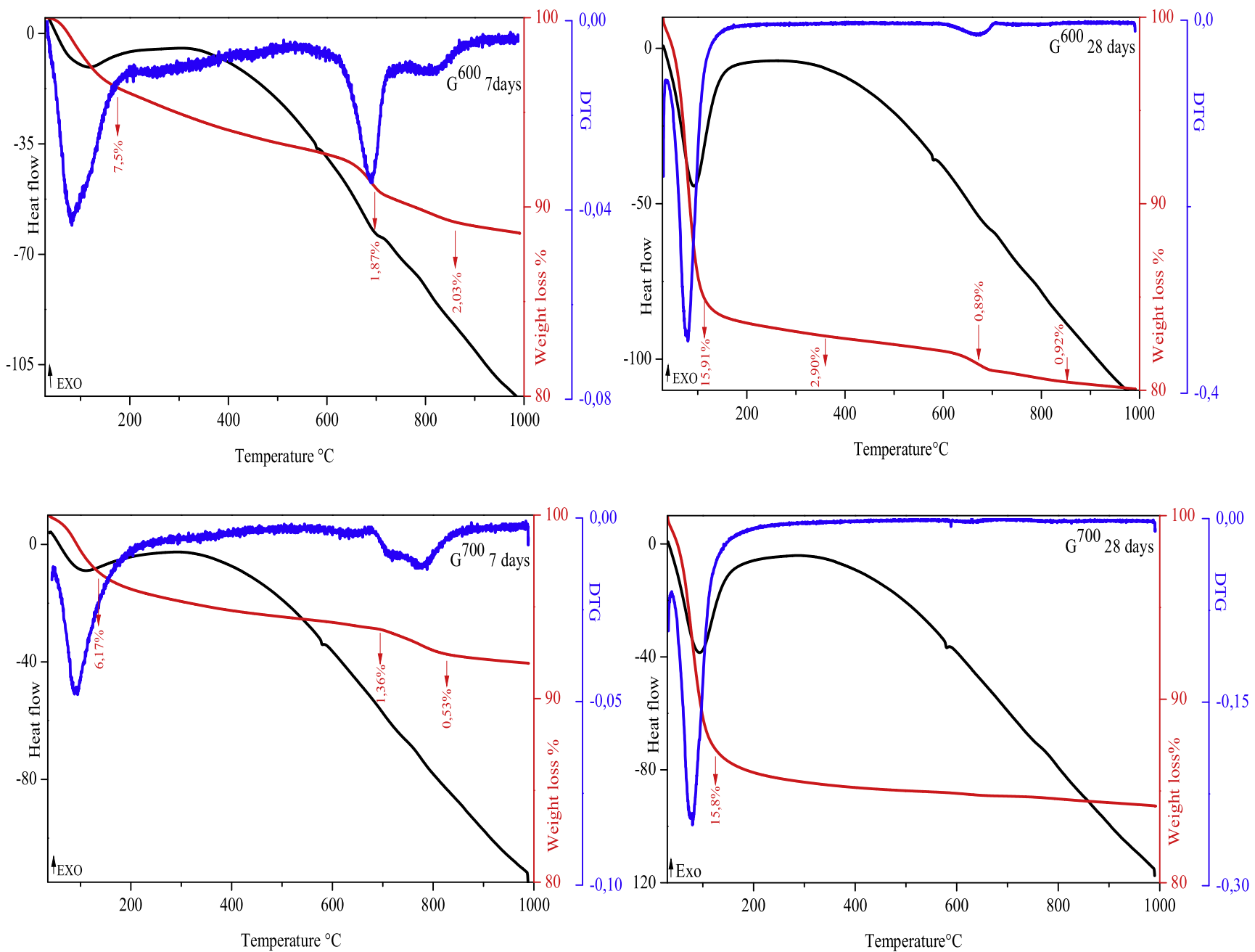

Fig. 10. DSC, TG-DTG of $\mathrm{G}^{600}$ and $\mathrm{G}^{700}$ at 7 and 28 days. 
The curves of $G_{0.9}^{600}$ at 7 and 28 days and the $G_{0.85}^{700}$ at 7 days present also other endothermic peak in an interval between $690^{\circ} \mathrm{C}$ and $750{ }^{\circ} \mathrm{C}$ which is associated to the rest of the calcium carbonate presents in the powder after calcination and also of the carbonate formed during the reaction.

It should be also mentioned that there are no other losses observed between $100^{\circ} \mathrm{C}$ and $1000^{\circ} \mathrm{C}$, the curve was of a smooth nature which reveals that the reaction products of the geopolymers mortars $G_{0.85}^{700}$ at 28 days is mainly amorphous gel with the physically and chemically bound water and no presence of hydrates in the crystalline form e.g. $\mathrm{Ca}(\mathrm{OH})_{2}, \mathrm{CaCO}_{3}$ or ettringite [75].

The curves of the DSC of all the samples show a small endothermic peak at $573{ }^{\circ} \mathrm{C}$ correspond to the allotropic transformation of quartz from quartz $\alpha$ quartz $\rightarrow \beta$.

\subsubsection{SEM characterization}

The scanning electron microscopy (SEM) images are presented in Figs. 11 and 12. Compared to the images of the calcined powder presented in Fig. 7, the microstructure of the samples show that the PWW, under the effect of the alkaline activator, reacts and generates reaction products.

The SEM of the matrix of the geopolymeric mortars shows a heterogeneous structure for the 2 samples but the $G_{0.85}^{700}$ present a more compact structure compared to $\mathrm{G}_{0.9}^{600}$. The micrographs present a little group of bright particles which are probably zeolite crystals with a very small size. On the other hand, the photos show the formation of amorphous aluminosilicate gel. The images show the interfacial area between the aggregate and the aluminosilicate gel matrix which mean that the adherence of the geopolymer
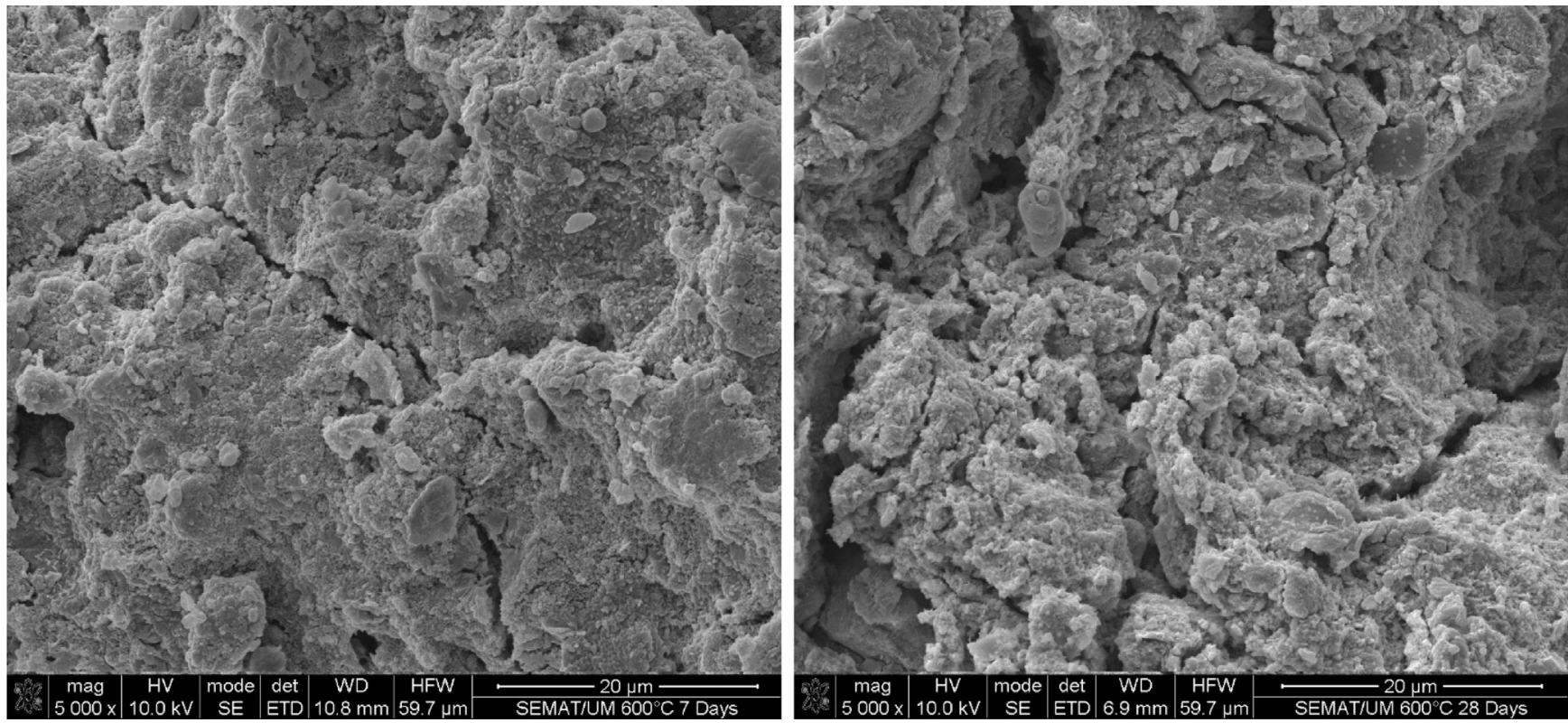

Fig. 11. SEM image of the geopolymer mortar $G_{0.9}^{600}$ at 7 and 28 days.
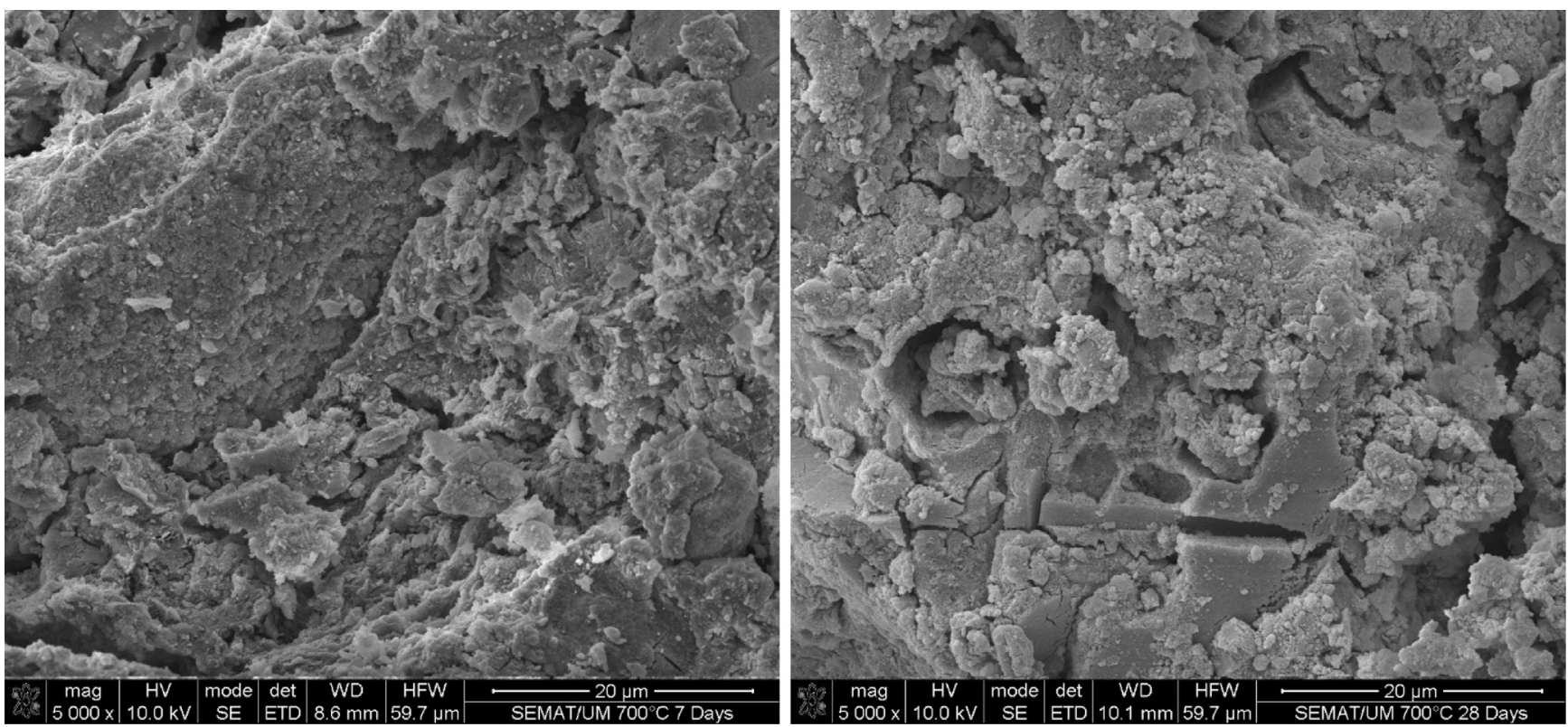

Fig. 12. SEM image of the geopolymer mortar $\mathrm{G}_{0.85}^{700}$ at 7 and 28 days. 


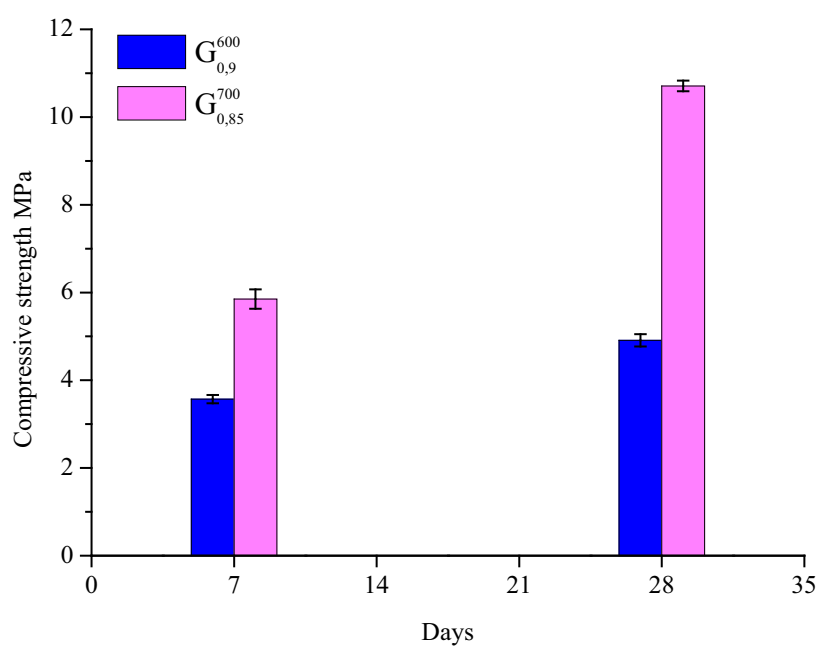

Fig. 13. compressive strength at 7 and 28 days.

mortars with the aggregate is good. We should also mention the presence and the formation of the carbonate in the matrices which confirms the DSC-TG and XRD analysis.

\subsubsection{Compressive strength}

Fig. 13 shows the compressive strength results of the mortars tested at the age of 7 and 28 days curing. The histogram shows that the strength of $\mathrm{G}_{0.9}^{600}$ and $\mathrm{G}_{0.85}^{700}$ at 7 days was not too much different $3.6 \pm 0.09 \mathrm{MPa}$ and $5.9 \pm 0.22 \mathrm{MPa}$ respectively. At 28 days the strength made a slight rise, it just becomes $4.9 \pm 0.14 \mathrm{MPa}$ which is about $36 \%$ for $\mathrm{G}_{0.9}^{600}$, but it is doubled from 5.9 to $10.7 \pm 0.12 \mathrm{MP}$ a which is about $81 \%$ for $G_{0.85}^{700}$ samples. Probably, this difference of the compressive strength can be explained by the difference of the geopolymer phases present in $G_{0.9}^{600}$ and $G_{0.85}^{700}$ which is the results of the destruction of the aluminosilcates phases comes from the heulandites and the palygorskite. In other hand this also can be interpreted by the amorphous phases and the $\mathrm{C}_{2} \mathrm{~S}$ present in the powder calcined at $700{ }^{\circ} \mathrm{C}$. According to Sanchez et al [76], the $\mathrm{C}_{2} \mathrm{~S}$ in alkali medium had a positive effect on the mechanical strength.

In $G_{0.85}^{700}$, the amount of extra water added to enhance the workability of the mixture was low compared to $\mathrm{G}_{0.9}^{600}$, so the concentration of the alkaline solution increased; signifying faster dissolution of the reactive components and promoting the polycondensation. Furthermore, the difference of the compressive strength between the $G_{0.9}^{600}$ and $G_{0.85}^{700}$ can also be explain by the presence and the amount of $\mathrm{CaO}$ in the calcined powder. According to Temunjim [77] and Garcia [78] the presence of calcium has a positive effect on the compressive strength of the samples cured at ambient temperature by forming amorphous structured $\mathrm{Ca}-\mathrm{Al}-\mathrm{Si}$ gel, the porosity of the microstructure decreased and the formed gel strengthens the final product. The reached compressive strength of $\mathrm{G}_{0.85}^{700}$ at 28 days can be suitable for an application as geopolymeric bricks can satisfying the requirement of BS 6073 for compressive strength $\geq 7 \mathrm{MPa}$ [79].

\section{Conclusion}

This paper presents the study of the effect of the calcination temperature on the PWW used as geopolymeric precursors. After this work it is possible to conclude that:

- Through the XRD characterization and the XRF analysis, it was possible to remark that the $\mathrm{PWW}$ is enriched with $\mathrm{SiO}_{2}, \mathrm{CaO}$, $\mathrm{P}_{2} \mathrm{O}_{5}$ and $\mathrm{Al}_{2} \mathrm{O}_{3}$ and had the heulandite, palygorskite, calcite and fluorapatite as major phases.
- The alkali activation of the PWW calcined at 3 different temperatures $600{ }^{\circ} \mathrm{C}, 700{ }^{\circ} \mathrm{C}$ and $800^{\circ} \mathrm{C}$, shows that the present phases in the calcined PWW and the composition of the mortar had an influence on the microstructure morphology, development of the products and consequently the mechanical properties of the corresponding mortars.

- The XRD of the geopolymeric mortars $G_{0.9}^{600}$ and $G_{0.85}^{700}$ show that the alkali activation of the calcined PWW generate 2 types of reactions: the formation of zeolite phases and aluminosilicate gel for the $G_{0.9}^{600}$ and the formation of aluminosilicate gel for $\mathrm{G}_{0.85}^{700}$.

- The compressive strength of the $G_{0.9}^{600}$ and $G_{0.85}^{700}$ did not evolve with the same manner. It remained steady for $G_{0.9}^{600}$ at 7 and 28 days, but it reached $\sim 11 \mathrm{MPa}$ at 28 days for $\mathrm{G}_{0.85}^{700}$ which is good enough for the application as geopolymeric bricks. This behaviour was related to the phases presented in the calcined materials and the composition of the samples preparation.

\section{Acknowledgment}

The authors acknowledge the Gafsa Phosphate Company "CPG Tunisia" for providing us the phosphate washing waste sample.

\section{Conflict of interest}

The authors declare that there is no conflcit of interest.

\section{References}

[1] I. Rucevska, C. Nellemann, N. Isarin, W. Yang, N. Liu, K. Yu, S. Sandnæs, K. Olley, H. McCann, L. Devia, Waste Crime-Waste Risks: Gaps in Meeting the Global Waste Challenge. A UNEP Rapid Response Assessment, 2017.

[2] Q. Song, J. Li, X. Zeng, Minimizing the increasing solid waste through zero waste strategy, J. Clean. Prod. 104 (2015) 199-210.

[3] A. Pappu, M. Saxena, S.R. Asolekar, Solid wastes generation in India and their recycling potential in building materials, Build. Environ. 42 (6) (2007) 23112320.

[4] B.G. Lottermoser, Recycling, reuse and rehabilitation of mine wastes, Elements 7 (6) (2011) 405-410.

[5] M.J.K. Ahmed, M. Ahmaruzzaman, A review on potential usage of industrial waste materials for binding heavy metal ions from aqueous solutions, J. Water Process Eng. 10 (2016) 39-47.

[6] J.A. Ober, Mineral commodity summaries 2018, Mineral Commodity Summaries, Reston, VA, 2018, p. 204.

[7] W. Gallala, M. Saïdi, S. el Hajii, K. Zayani, M.E. Gaied, M. Montacer, Characterization and valorization of Tozeur-Nefta phosphate ore deposit (Southwestern Tunisia), Proc. Eng. 138 (2016) 8-18.

[8] K. Boughzala, N.F.K. Bouzouita, H.B. Hassine, Etude minéralogique et chimique du phosphate naturel d'Oum El Khecheb (Gafsa, Tunisie).

[9] S. Elgharbi, K. Horchani-Naifer, M. Ferid, Investigation of the structural and mineralogical changes of Tunisian phosphorite during calcinations, J. Therm. Anal. Calorim. 119 (1) (2015) 265-271.

[10] A.J. Notholt, Phosphate deposits of the world, Sl1989.

[11] N.K. Lee, H.K. Lee, Reactivity and reaction products of alkali-activated, fly ash/ slag paste, Constr. Build. Mater. 81 (2015) 303-312.

[12] M. Mastali, Z. Abdollahnejad, F. Pacheco-Torgal, Performance of waste based alkaline mortars submitted to accelerated carbon dioxide curing, Resour. Conserv. Recycling 129 (2018) 12-19.

[13] Messina, Ferone, Colangelo, Roviello, Cioffi, Alkali activated waste fly ash as sustainable composite: influence of curing and pozzolanic admixtures on the early-age physico-mechanical properties and residual strength after exposure at elevated temperature, Compos. Part B: Eng. 132 (2018) 161-169.

[14] W. Tahri, Z. Abdollahnejad, J. Mendes, F. Pacheco-Torgal, J.B. de Aguiar, Performance of a fly ash geopolymeric mortar for coating of ordinary portland cement concrete exposed to harsh chemical environments, Adv. Mater. Res. 1129 (2015) 573-580.

[15] J.L. Provis, S.A. Bernal, Geopolymers and related alkali-activated materials, Annu. Rev. Mater. Res. 44 (1) (2014) 299-327.

[16] Z. Abdollahnejad, F. Pacheco-Torgal, T. Félix, W. Tahri, J.B. Aguiar, Mix design, properties and cost analysis of fly ash-based geopolymer foam, Constr. Build. Mater. 80 (2015) 18-30.

[17] A.M. Cardoso, A. Paprocki, L.S. Ferret, C.M.N. Azevedo, M. Pires, Synthesis of zeolite Na-P1 under mild conditions using Brazilian coal fly ash and its application in wastewater treatment, Fuel 139 (2015) 59-67.

[18] M.S. Khan, M. Sohail, N.S. Khattak, M. Sayed, Industrial ceramic waste in Pakistan, valuable material for possible applications, J. Clean. Prod. 139 (2016) 1520-1528. 
[19] S.K. Amin, S.A. El-Sherbiny, A.A.M.A. El-Magd, A. Belal, M.F. Abadir, Fabrication of geopolymer bricks using ceramic dust waste, Constr. Build. Mater. 157 (2017) 610-620.

[20] K. Rashid, A. Razzaq, M. Ahmad, T. Rashid, S. Tariq, Experimental and analytical selection of sustainable recycled concrete with ceramic waste aggregate, Constr. Build. Mater. 154 (2017) 829-840.

[21] P. Muñoz Velasco, M.P. Morales Ortíz, M.A. Mendívil Giró, L. Muñoz Velasco, Fired clay bricks manufactured by adding wastes as sustainable construction material - a review, Constr. Build. Mater. 63 (2014) 97-107.

[22] N. Maatoug, G. Delahay, H. Tounsi, Valorization of vitreous China waste to EMT/FAU, FAU and Na-P zeotype materials, Waste Manage. 74 (2018) 267278.

[23] D.E. Angulo-Ramírez, R. Mejía de Gutiérrez, F. Puertas, Alkali-activated Portland blast-furnace slag cement: mechanical properties and hydration, Constr. Build. Mater. 140 (2017) 119-128.

[24] L. Ding, W. Ning, Q. Wang, D. Shi, L. Luo, Preparation and characterization of glass-ceramic foams from blast furnace slag and waste glass, Mater. Lett. 141 (2015) 327-329.

[25] N. Toniolo, A. Rincón, Y.S. Avadhut, M. Hartmann, E. Bernardo, A.R. Boccaccini, Novel geopolymers incorporating red mud and waste glass cullet, Mater. Lett. 219 (2018) 152-154.

[26] S.Y. Choi, Y.S. Choi, E.I. Yang, Effects of heavy weight waste glass recycled as fine aggregate on the mechanical properties of mortar specimens, Ann. Nucl. Energy 99 (2017) 372-382.

[27] M. Mastali, Z. Abdollahnejad, F. Pacheco-Torgal, Carbon dioxide sequestration of fly ash alkaline-based mortars containing recycled aggregates and reinforced by hemp fibres, Constr. Build. Mater. 160 (2018) 48-56.

[28] Heriyanto, F. Pahlevani, V. Sahajwalla, From waste glass to building materials - an innovative sustainable solution for waste glass, J. Clean. Prod. 191 (2018) 192-206.

[29] J.-X. Lu, C.S. Poon, Use of waste glass in alkali activated cement mortar, Constr. Build. Mater. 160 (2018) 399-407.

[30] F. Andreola, L. Barbieri, I. Lancellotti, C. Leonelli, T. Manfredini, Recycling of industrial wastes in ceramic manufacturing: state of art and glass case studies, Ceram. Int. 42 (12) (2016) 13333-13338.

[31] C. Belviso, A. Kharchenko, E. Agostinelli, F. Cavalcante, D. Peddis, G. Varvaro, N. Yaacoub, S. Mintova, Red mud as aluminium source for the synthesis of magnetic zeolite, Microporous Mesoporous Mater. 270 (2018) 24-29.

[32] W. Wang, W. Chen, H. Liu, C. Han, Recycling of waste red mud for production of ceramic floor tile with high strength and lightweight, J. Alloys Comp. 748 (2018) 876-881.

[33] T. Bai, Z.-G. Song, Y.-G. Wu, X.-D. Hu, H. Bai, Influence of steel slag on the mechanical properties and curing time of metakaolin geopolymer, Ceram. Int. (2018).

[34] Y. Jiang, T.-C. Ling, C. Shi, S.-Y. Pan, Characteristics of steel slags and their use in cement and concrete-a review, Resour. Conserv. Recycling 136 (2018) 187197.

[35] A. Siddiqui, M. Pal, D. Bhattacharya, S. Das, Iron and steel slag: an alternative source of raw materials for porcelain ceramics, Global NEST J. 16 (4) (2014) 587-596.

[36] S. Jellali, M.A. Wahab, M. Anane, K. Riahi, L. Bousselmi, Phosphate mine wastes reuse for phosphorus removal from aqueous solutions under dynamic conditions, J. Hazard. Mater. 184 (1-3) (2010) 226-233.

[37] Q. Chen, Q. Zhang, A. Fourie, C. Xin, Utilization of phosphogypsum and phosphate tailings for cemented paste backfill, J. Environ. Manage. 201 (2017) $19-27$.

[38] R. Hakkou, M. Benzaazoua, B. Bussière, Valorization of phosphate waste rocks and sludge from the moroccan phosphate mines: challenges and perspectives, Proc. Eng. 138 (2016) 110-118.

[39] A.M. Rashad, Phosphogypsum as a construction material, J. Clean. Prod. 166 (2017) 732-743.

[40] A.-Z.M.A.A.A. Negm, Utilization of solid wastes from phosphate process, Physicochem. Problems Miner. Process. 42 (2008) 5-16.

[41] M. Khemakhem, S. Khemakhem, S. Ayedi, R.B. Amar, Study of ceramic ultrafiltration membrane support based on phosphate industry subproduct: application for the cuttlefish conditioning effluents treatment, Ceram. Int. 37 (8) (2011) 3617-3625

[42] M. Khemakhem, S. Khemakhem, S. Ayedi, M. Cretin, R. Ben Amar, Development of an asymmetric ultrafiltration membrane based on phosphates industry subproducts, Ceram. Int. 41 (9) (2015) 10343-10348.

[43] Y. Yang, Z. Wei, Y.-L. Chen, Y. Li, X. Li, Utilizing phosphate mine tailings to produce ceramisite, Constr. Build. Mater 155 (2017) 1081-1090.

[44] M. Loutou, M. Hajjaji, M. Mansori, C. Favotto, R. Hakkou, Phosphate sludge: thermal transformation and use as lightweight aggregate material, J. Environ. Manage. 130 (2013) 354-360.

[45] X. Liu, Y. Zhang, T. Liu, Z. Cai, K. Sun, Characterization and separation studies of a fine sedimentary phosphate ore slime, Minerals 7 (6) (2017) 94.

[46] M.N. Rashed, A.R. Mohamed, M.A. Awadallah, Chemically activated phosphate slime as adsorbent for heavy metals removal from polluted water, Int. J. Environ. Waste Manage. 16 (2) (2015) 145-165.

[47] R. Chraiti, M. Raddaoui, A. Hafiane, Effluent water quality at phosphate mines in M'Dhilla, Tunisia and its potential environmental effects, Mine Water Environ. 35 (4) (2016) 462-468.

[48] R. Daik, M. Lajnef, S.B. Amor, H. Ezzaouia, Effect of the temperature and the porosity of the gettering process on the removal of heavy metals from Tunisian phosphate rock, Results Phys. 7 (2017) 4189-4194.
[49] I. Barrouk, S. Alami Younssi, A. Kabbabi, M. Persin, A. Albizane, S. Tahiri, New ceramic membranes from natural Moroccan phosphate for microfiltration application, Desalin. Water Treatm. 55(1) (2014) 53-60.

[50] M. Mouiya, A. Abourriche, A. Bouazizi, A. Benhammou, Y. El Hafiane, Y Abouliatim, L. Nibou, M. Oumam, M. Ouammou, A. Smith, H. Hannache, Flat ceramic microfiltration membrane based on natural clay and Moroccan phosphate for desalination and industrial wastewater treatment, Desalination 427 (2018) 42-50.

[51] W. Gallala, F. Herchi, I.B. Ali, L. Abbassi, M.E. Gaied, M. Montacer, Beneficiation of phosphate solid coarse waste from redayef (Gafsa mining basin) by grinding and flotation techniques, Proc. Eng. 138 (2016) 85-94.

[52] A. Negm, A. Abouzeid, Utilization of solid wastes from phosphate processing plants, Physicochem. Problems Miner. Process. 42 (2008) 5-16.

[53] M. Loutou, M. Hajjaji, M.A. Babram, M. Mansori, C. Favotto, R. Hakkou, Phosphate sludge-based ceramics: microstructure and effects of processing factors, J. Build. Eng. 11 (2017) 48-55.

[54] A. Ahmed, M. Abdel-zaher, An environmental solution for phosphate coarse waste reject-using them as concrete mix aggregates, J. Eng. Sci. Assiut Univ. Faculty Eng. 42 (4) (2014) 1094-1105.

[55] J. Davidovits, Geopolymers: inorganic polymeric new materials, J. Therm. Anal. Calorim. 37 (8) (1991) 1633-1656.

[56] H. Xu, J.S. Van Deventer, Geopolymerisation of multiple minerals, Miner. Eng 15 (12) (2002) 1131-1139.

[57] W. Tahri, B. Samet, F.M.A.S.P. Torgal, J. Aguiar, S. Baklouti, Geopolymeric repair mortars based on a low reactive clay, Eco-efficient Repair Rehabil. Concr. Infrastruct. 1 (2017) 293-313.

[58] D. Panias, I.P. Giannopoulou, T. Perraki, Effect of synthesis parameters on the mechanical properties of fly ash-based geopolymers, Colloids Surf. A: Physicochem. Eng. Aspects 301 (1-3) (2007) 246-254.

[59] F. Pacheco-Torgal, Z. Abdollahnejad, S. Miraldo, M. Kheradmand, AlkaliActivated Cement-Based Binders (AACBs) as Durable and Cost-Competitive Low-CO2 Binder Materials: Some Shortcomings that need to be Addressed, Butterworth-Heinemann, Oxford, UK, 2017.

[60] S. Louati, S. Baklouti, B. Samet, Acid based geopolymerization kinetics: effect of clay particle size, Appl. Clay Sci. 132-133 (2016) 571-578.

[61] S. Louati, S. Baklouti, B. Samet, Geopolymers based on phosphoric acid and illito-kaolinitic clay, Adv. Mater. Sci. Eng. 2016 (2016).

[62] S. Louati, W. Hajjaji, S. Baklouti, B. Samet, Structure and properties of new ecomaterial obtained by phosphoric acid attack of natural Tunisian clay, Appl Clay Sci. 101 (2014) 60-67.

[63] S. Cunha, J.B. Aguiar, A. Tadeu, Thermal performance and cost analysis of mortars made with PCM and different binders, Constr. Build. Mater. 122 (2016) 637-648.

[64] E. European Committee for Standardization CEN, 1015-3, Methods of test for mortar for masonry-Part 3: Determination of consistence of fresh mortar (by flow table), 2004, pp. 1-10.

[65] A. Aissa, A. Abdeen, M. Abualreish, Qualitative and quantitative analysis of phosphate rock from Hazm Al-jalamid area, northern Saudi Arabia, 2014.

[66] M. Suárez, E. García-Romero, FTIR spectroscopic study of palygorskite: influence of the composition of the octahedral sheet, Appl. Clay Sci. 31 (1-2) (2006) 154-163.

[67] F. Ben Ayed, J. Bouaziz, K. Bouzouita, Pressureless sintering of fluorapatite under oxygen atmosphere, J. Eur. Ceram. Soc. 20 (8) (2000) 1069-1076.

[68] S. Gunasekaran, G. Anbalagan, Spectroscopic characterization of natural calcite minerals, Spectrochim. Acta A Mol. Biomol. Spectrosc. 68 (3) (2007) 656-664.

[69] F.B. Reig, J.V.G. Adelantado, M.C.M. Moya Moreno, FTIR quantitative analysis of calcium carbonate (calcite) and silica (quartz) mixtures using the constant ratio method. Application to geological samples, Talanta 58 (4) (2002) 811-821.

[70] J.L. Bishop, M.D. Lane, M.D. Dyar, S.J. King, A.J. Brown, G.A. Swayze, Spectral properties of Ca-sulfates: gypsum, bassanite, and anhydrite, Am. Mineral. 99 (10) (2014) 2105-2115.

[71] J.F. Gelves, G.S. Gallego, M.A. Marquez, Mineralogical characterization of zeolites present on basaltic rocks from Combia geological formation, La Pintada (Colombia), Microporous Mesoporous Mater. 235 (Suppl. C) (2016) 9-19.

[72] M. Ostrooumov, P. Cappelletti, R. de'Gennaro, Mineralogical study of zeolite from New Mexican deposits (Cuitzeo area, Michoacan, Mexico), Appl. Clay Sci. 55 (2012) 27-35.

[73] S. Astutiningsih, Y. Liu, Geopolymerisation of Australian slag with effective dissolution by the alkali, in: Proceedings of the World Congress Geopolymer Saint Quentin, France, 2005, pp. 69-73.

[74] Z. Zuhua, Y. Xiao, Z. Huajun, C. Yue, Role of water in the synthesis of calcined kaolin-based geopolymer, Appl. Clay Sci. 43 (2) (2009) 218-223.

[75] F. Škvára, L. Kopecký, V. Šmilauer, Z. Bittnar, Material and structura characterization of alkali activated low-calcium brown coal fly ash, J Hazard. Mater. 168 (2) (2009) 711-720.

[76] M.J. Sánchez-Herrero, A. Fernández-Jiménez, Á. Palomo, L. Klein, Alkaline hydration Of C2S and C3S, J. Am. Ceram. Soc. 99 (2) (2016) 604-611.

[77] J.V. Temuujin, A. Van Riessen, R. Williams, Influence of calcium compounds on the mechanical properties of fly ash geopolymer pastes, J. Hazard. Mater. 167 (1-3) (2009) 82-88.

[78] I. Garcia-Lodeiro, E. Aparicio-Rebollo, A. Fernández-Jimenez, A. Palomo, Effect of calcium on the alkaline activation of aluminosilicate glass, Ceram. Int. 42 (6) (2016) 7697-7707.

[79] M.M.A. Abdullah, W.M.W. Ibrahim, M.F.M. Tahir, 12 - The properties and durability of fly ash-based geopolymeric masonry bricks, Eco-Efficient Masonry Bricks and Blocks, Woodhead Publishing, Oxford, 2015, pp. 273-287. 